\title{
Nursing Students' Anxiety Levels and Coping Strategies during the COVID-19 Pandemic
}

\author{
Zeynep Temiz, PhD* \\ Assistant Professor, Department of Surgical Nursing, Artvin Çoruh University, Artvin, Turkey
}

*Corresponding author: Zeynep Temiz, PhD, Assistant Professor, Department of Surgical Nursing, Faculty of Health Sciences, Artvin Çoruh University, City Campüs, Çayağzı District, Center/Artvin, Turkey, Tel: +90-466-215-10-00/2134

\begin{abstract}
Background: Anxiety is very prevalent among nursing students even in normal circumstances. In Turkey during the COVID-19 pandemic, nursing students encountered a new reality of that includes economic uncertainty, fear of infection, the challenges of distance education and more.

Aim: This study was carried out to determine the relationship between the anxiety levels and the coping methods of nursing students during the COVID-19 pandemic.

Material and method: This cross-sectional study was conducted at a University in the Eastern Black Sea region of Turkey between July 3-10, 2020. The sample was composed of 316 nursing students. A personal information form, the Generalized Anxiety Disorder-7 Scale and the Stress Coping Strategies Scale were used. The data were evaluated using descriptive statistics, the Mann-Whitney $U$ test, the Kruskal-Wallis test and Spearman's correlation test.
\end{abstract}

Results: Of the students, $40.5 \%$ had moderate anxiety. The students who lived in the Marmara region (median: 8 ) and who had jobs (median: 10) had significantly higher anxiety levels $(p<0.05)$. The restriction of social life ( $r: 322, p<$ 0.01 ) had the highest correlation among the factors that caused the students to experience anxiety. It was determined that the students used the eating coping method the most (48.1\%), and there was a significant negative relationship between the self-confident approach, seeking social support and anxiety levels ( $p<0.01)$.

Conclusion: The nursing students experienced moderate anxiety during the COVID-19 pandemic. A negative relationship was found between the self-confident approach, seeking social support and the students' anxiety levels during the pandemic.

\section{Keywords}

Anxiety, Coping strategies, COVID-19, Nursing students, Pandemic

\section{Introduction}

The COVID-19 virus, which was first observed toward the end of 2019, was declared a pandemic by the World Health Organization (WHO) on March 11, 2020 because 118,000 people had been infected and 4,291 people had died from the virus [1]. The first COVID-19 case in Turkey was seen on March 10,2020, and the number of infections grew gradually [2]. The total number of cases in Turkey was 198.284, and the number of deaths was 5,097 on June 30,2020 when this study was written [3].

The COVID-19 pandemic has caused many problems in the world as well as in Turkey. Education has been among these problems. Similarly with many other countries, schools were closed as a measure against COVID-19 in Turkey [4-6]. On March 26, 2020, the Counsel of Higher Education declared that no face-to-face classes would be held in the spring term of the 20192020 academic year because of uncertainty about the pandemic, and distance education was put on the agenda in Turkey [7].

Since nursing students carry out their internships and applied courses in clinics, they were one of the groups that experienced the most problems during the COVID-19 pandemic. The students experienced anxiety because they were not able to perform clinical practices, and their classes and exams were carried out as distance education [8].

A study conducted before the COVID-19 pandemic to evaluate the anxiety of university students found that their most important anxieties were academic performance, pressure to succeed and post-graduation plans

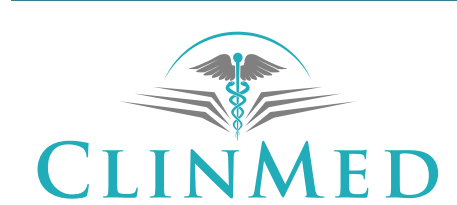

INTERNATIONAL LIBRARY 
[9]. A systematic review carried out during the pandemic found that university students' problems due to the COVID-19 pandemic: Were "transition from face-toface classes to web-based classes", "how exams will be held", "transportation restrictions", "mental health", and "the support of the university" [4]. Another study investigated the problems of nursing students during the pandemic and found that most of them had difficulty keeping up with their classes because they had difficulty coping with anxiety, stress and moods caused by the pandemic [8]. Another study investigating the anxiety and the coping strategies of nursing students found that $42.8 \%$ of them experienced moderate anxiety, and also found significant relationships between high self-esteem, the use of humor and anxiety levels [10]. A study carried out in China found that university students experienced anxiety because they lived in rural areas during this crisis and because of uncertain family income levels [11]. Self-protection concerns during the pandemic reduced the students' ability to concentrate on their classes and negatively affected their mental health $[6,11,12]$.

Nursing students' professional identity development and health are negatively affected by stress and anxiety $[13,14]$. These negative effects are directly associated with their coping behaviors $[15,16]$. Previous studies have showed that students do not use effective coping strategies during stressful situations [17,18]. Few studies have investigated the anxiety and stress coping strategies of nursing students during the pandemic.

This study aims to evaluate the anxiety levels and coping strategies of nursing students during the COVID-19 pandemic. This study is considered to contribute to the establishment of programs that will help nursing students to cope with stress by determining their stress levels during the pandemic.

Here are its research questions:

- What were the anxiety levels of the students during the pandemic?

- What were the important events that caused them anxiety and stress during the pandemic?

- Was there a relationship between the perceived anxiety levels and the stress coping strategies of the students during the pandemic?

\section{Methods}

\section{Design}

This is a cross-sectional study.

\section{Participants}

The population of the study was made up of $1^{\text {st }}, 2^{\text {nd }}$, $3^{\text {rd }}$ and $4^{\text {th }}$ year students $(n=352)$ attending the Nursing Department, Faculty of Health Sciences, a state university in the East Black Sea region of Turkey during the spring semester of the 2019-2020 academic year. This study did not perform a sampling and aimed to reach all of the population. Nursing students who agreed to participate were included in the study after an ethical approval was obtained. However, 15 students of the 331 student who agreed to participate in the study were excluded because they did not completely fill out the questionnaire, so the study sample included 316 students, $89.8 \%$ of the study population.

\section{Procedure}

This study was approved by Research Ethics Committee of Artvin Coruh University (number 20478486-405, Date: 24.06.2020). Since the study was not conducted with patients, permission was not obtained from Ministry of Health Scientific Research Platform. The data collection forms were uploaded to http://www.surveey. com/, and the link was emailed to the students. The home page of the questionnaire included an informed consent form for the students, and the students who agreed to participate were able to continue to the questionnaire. The questionnaires were collected from July 3 to July 10, 2020.

\section{Instruments}

After ethical approval, the data were collected using a web-based questionnaire that includes 10 open-ended and close-ended questions about sociodemographic data, problems experienced by nursing students during the COVID-19 pandemic, and coping strategies. The students' anxiety levels were determined using the Generalized Anxiety Disorder-7 Scale. Their coping strategies were determined using the Stress Coping Strategies Scale.

The Generalized Anxiety Disorder-7 Scale (GAD-7) developed by Spitzer, et al. [19]. Its validity and reliability study was carried out by Konkan, et al. [20]. The Generalized Anxiety Disorder-7 Scale (GAD-7) is composed of 7 items. They are 4-point Likert-type items. The Cronbach's alpha value of the scale is 0.85 . Cronbach's Alpha value is 0.80 for this study. Scores from 0 to 4 indicate mild level anxiety. Scores from 5 to 9 indicate moderate level anxiety. Scores from 10 to 14 indicate high level anxiety, and scores from 15 to 21 indicate severe anxiety. The acceptable cut-off value of the scale is 8 [20]. Range values were used for this study.

The Stress Coping Strategies Scale developed by Folkman ve Lazarus [21]. Its validity and reliability study was carried out by Şahin and Durak [22]. The Stress Coping Strategies Scale has 5 subscales: The self-confident approach, the desperate approach, the submissive approach, the optimistic approach and seeking social support. This scale is composed of 30 items, which are scored from 0 to 3 . No total score is calculated. The subscales were scored separately. The highest score is 3 for the subscales. The lowest score is 0 for the subscales. Higher scores on the self-confident, optimistic and seek- 
ing social support factors indicate the use of effective methods to cope with stress. Higher scores on the desperate and submissive factors indicate the use of ineffective methods to cope with stress. The Cronbach's alpha values of the subscales were: 0.80 for the self-confident approach, 0.68 for the optimistic approach, 0.73 for the desperate approach, 0.70 for the submissive approach and 0.47 for seeking social support [22]. In this study, the Cronbach's alpha values of the subscales were: 0.75 for the self-confident approach, 0.65 for the optimistic approach, 0.70 for the desperate approach, 0.68 for the submissive approach and 0.50 for seeking social support.

\section{Data analysis}

The data were evaluated using SPSS 20.0 software. The Shapiro-Wilk test was used to test the normality of the distribution of continuous measurements, which were not normally distributed. Means, medians and interquartile ranges were used as descriptive statistics. The Mann-Whitney $U$ test and the Kruskal-Wallis test were used for comparisons, and the Bonferroni test was used to determine the groups that caused differences. Spearman's correlation coefficient was used to determine the relationships between anxiety scores and subscale scores on the stress coping strategies scale. The results were assessed at a $95 \%$ confidence interval, and the threshold for statistical significance was $p<0.05$.

\section{Results}

Table 1 shows the distribution of students' sociodemographic characteristics. Their mean age was $21.25 \pm$ 1.65. Of them, $72.2 \%$ were female, $27.5 \%$ were in their first year of study, $32 \%$ lived in southeastern Anatolia, and $89.9 \%$ lived with their families. Of them, $90.2 \%$ did not have a chronic illness, $91.8 \%$ had no relatives or friends infected with COVID-19, and $89.9 \%$ did not have a job during the pandemic (Table 1 ).

Total scores on the GAD-7 scale were calculated to determine the students' anxiety levels. Table 2 shows the students' mean score on the Generalized Anxiety Disorder-7 Scale and the distribution based on their anxiety levels. The median value for the students' score on the Generalized Anxiety Disorder-7 Scale was 6.0 (3.0-10.0). Their anxiety levels are shown with the cutoff points of the scale. Table 2 shows that $32.3 \%$ of the students had mild anxiety, $40.5 \%$ had moderate anxiety, $22.5 \%$ had high anxiety, and $4.7 \%$ had severe anxiety during the COVID-19 pandemic (Table 2).

Comparison of the students' Generalized Anxiety Disorder-7 Scale scores and their sociodemographic characteristics found that the students who were younger than 21 (median $=7.0$ ), who were female (median $=6.0$ ), who were in their fourth year of study (median $=7.0$ ), who had a chronic illness (median $=7$ ), and who lived with their families (median $=6.0$ ) had higher
Table 1: Distribution of the students' sociodemographic characteristics $(\mathrm{N}=316)$.

\begin{tabular}{|c|c|}
\hline Characteristics & n (\%) \\
\hline Age (Mean \pm SD) & $21.25 \pm 1.65$ \\
\hline $\begin{array}{l}\text { Year of Study } \\
1^{\text {st }} \text { year } \\
2^{\text {nd }} \text { year } \\
3^{\text {rd }} \text { year } \\
4^{\text {th }} \text { year }\end{array}$ & $\begin{array}{l}87(27.5 \%) \\
79(25.0 \%) \\
77(24.4 \%) \\
73(23.1 \%)\end{array}$ \\
\hline $\begin{array}{l}\text { Gender } \\
\text { Female } \\
\text { Male }\end{array}$ & $\begin{array}{l}228(72.2 \%) \\
88(27.8 \%)\end{array}$ \\
\hline $\begin{array}{l}\text { Place of residence during the pandemic } \\
\text { Marmara region } \\
\text { Mediterranean region } \\
\text { Aegean region } \\
\text { Central Anatolia } \\
\text { East Anatolia } \\
\text { Black Sea region } \\
\text { Southeastern Anatolia }\end{array}$ & $\begin{array}{l}24(7.6 \%) \\
59(18.7 \%) \\
5(1.6 \%) \\
20(6.3 \%) \\
47(14.9 \%) \\
60(19.0 \%) \\
101(32.0 \%)\end{array}$ \\
\hline $\begin{array}{l}\text { With whom have you been living with } \\
\text { during the pandemic? } \\
\text { Family } \\
\text { Friends } \\
\text { Alone }\end{array}$ & $\begin{array}{l}284(89.9 \%) \\
27(8.5 \%) \\
5(1.6 \%)\end{array}$ \\
\hline $\begin{array}{l}\text { Do you have a chronic illness? } \\
\text { Yes } \\
\text { No }\end{array}$ & $\begin{array}{l}31(9.8 \%) \\
285(90.2 \%)\end{array}$ \\
\hline $\begin{array}{l}\text { Have you or any of your relatives been } \\
\text { infected with Covid-19? } \\
\text { Yes } \\
\text { No }\end{array}$ & $\begin{array}{l}26(8.2 \%) \\
290(91.8 \%)\end{array}$ \\
\hline $\begin{array}{l}\text { Have you had a job during the pandemic? } \\
\text { Yes } \\
\text { No }\end{array}$ & $\begin{array}{l}32(10.1 \%) \\
284(89.9 \%)\end{array}$ \\
\hline
\end{tabular}

median values. However, these differences were not significant ( $p>0.05$ ) (Table 2). The median value of the anxiety score of students living in the Marmara region was the highest (8.0), and the median value of the students living in the Black Sea region was the lowest (5.0). This difference was statistically significant $(p<0.001)$. The students who worked during the pandemic also had significantly higher anxiety score median values $(10.0, p$ $<0.001$ ) (Table 2).

The results of the correlation analysis between the COVID-19-related stressors and anxiety are shown in Table 3. There were positive relationships between the students' anxiety scores and their family, educational, economic, health problems and restriction of social life (Table 3).

The most commonly used anxiety coping strategy was spending time on the internet (77.8\%), and the least commonly used coping strategy was exercising (38.6\%) (Table 4). 
Table 2: The anxiety levels of the nursing students and their demographic characteristics $(N=316)$.

\begin{tabular}{|c|c|c|c|c|c|c|c|c|c|}
\hline & \multicolumn{2}{|c|}{ Mild } & \multicolumn{2}{|c|}{ Moderate } & \multicolumn{2}{|c|}{ High } & \multicolumn{2}{|c|}{ Severe } & \multirow{2}{*}{$\begin{array}{l}\text { Total score } \\
\text { Median (IQR) }\end{array}$} \\
\hline & $\mathbf{n}$ & $\%$ & $\mathbf{n}$ & $\%$ & $\mathbf{n}$ & $\%$ & $\mathbf{n}$ & $\%$ & \\
\hline $\begin{array}{l}\text { Generalized Anxiety } \\
\text { Disorder (GAD)-7 }\end{array}$ & 102 & 32.3 & 128 & 40.5 & 71 & 22.5 & 15 & 4.7 & $6.0(3.0-10.0)$ \\
\hline \multicolumn{5}{|c|}{ Demographic characteristics } & \multicolumn{2}{|c|}{ Mean (SD) } & \multicolumn{2}{|c|}{ Median (IQR) } & P value \\
\hline Age* $^{*}$ & \multicolumn{4}{|c|}{$\begin{array}{l}21 \text { or younger } \\
22 \text { and/or older }\end{array}$} & \multicolumn{2}{|c|}{$\begin{array}{l}6.85 \pm 4.63 \\
6.54 \pm 4.37\end{array}$} & \multicolumn{2}{|c|}{$\begin{array}{l}7.0(3.0-10.0) \\
6.0(3.0-9.0)\end{array}$} & 0.432 \\
\hline Gender* & \multicolumn{4}{|c|}{$\begin{array}{l}\text { Female } \\
\text { Male }\end{array}$} & \multicolumn{2}{|c|}{$\begin{array}{l}6.74 \pm 4.67 \\
6.67 \pm 4.13\end{array}$} & \multicolumn{2}{|c|}{$\begin{array}{l}6.0(3.0-10.0) \\
6.0(4.0-9.0)\end{array}$} & 0.879 \\
\hline Year of study** & \multicolumn{4}{|c|}{$\begin{array}{l}1^{\text {st }} \text { year } \\
2^{\text {nd }} \text { year } \\
3^{\text {rd }} \text { year } \\
4^{\text {th }} \text { year }\end{array}$} & \multicolumn{2}{|c|}{$\begin{array}{l}6.93 \pm 4.32 \\
6.24 \pm 3.77 \\
6.28 \pm 4.76 \\
7.38 \pm 5.15\end{array}$} & \multicolumn{2}{|c|}{$\begin{array}{l}8.0(2.0-10.0) \\
6.0(4.0-9.0) \\
5.0(2.5-10.0) \\
7.0(4.0-10.0)\end{array}$} & 0.073 \\
\hline Chronic illness* & \multicolumn{4}{|l|}{$\begin{array}{l}\text { Yes } \\
\text { No }\end{array}$} & \multicolumn{2}{|c|}{$\begin{array}{l}7.12 \pm 5.27 \\
6.67 \pm 4.44\end{array}$} & \multicolumn{2}{|c|}{$\begin{array}{l}7.0(3.0-12.0) \\
6.0(4.0-9.5)\end{array}$} & 0.680 \\
\hline Place of residence ${ }^{* *}$ & \multicolumn{4}{|c|}{$\begin{array}{l}\text { Marmara } \\
\text { Mediterranean } \\
\text { Aegean } \\
\text { Central Anatolia } \\
\text { Eastern } \\
\text { Anatolia } \\
\text { Black Sea } \\
\text { South eastern Anatolia }\end{array}$} & \multicolumn{2}{|c|}{$\begin{array}{l}9.20 \pm 5.21 \\
8.19 \pm 4.78 \\
5.50 \pm 3.25 \\
5.45 \pm 4.09 \\
6.48 \pm 4.45 \\
5.53 \pm 4.25 \\
7.03 \pm 4.60\end{array}$} & \multicolumn{2}{|c|}{$\begin{array}{l}8.0(6.0-11.0) \\
7.0(5.0-14.5) \\
5.5(3.0-7.5) \\
6.0(1.0-8.0) \\
6.0(3.0-10.0) \\
5.0(2.0-8.0) \\
7.0(4.0-10.0)\end{array}$} & 0.000 \\
\hline Co-residents ${ }^{* *}$ & \multicolumn{4}{|c|}{$\begin{array}{l}\text { Family } \\
\text { Friends } \\
\text { Alone }\end{array}$} & \multicolumn{2}{|c|}{$\begin{array}{l}6.77 \pm 4.57 \\
6.48 \pm 4.30 \\
4.80 \pm 2.77\end{array}$} & \multicolumn{2}{|c|}{$\begin{array}{l}6.0(3.0-10.0) \\
5.0(3.0-9.0) \\
4.0(2.5-7.5)\end{array}$} & 0.905 \\
\hline Do you have a job?* & \multicolumn{4}{|l|}{$\begin{array}{l}\text { Yes } \\
\text { No }\end{array}$} & \multicolumn{2}{|c|}{$\begin{array}{l}9.5 \pm 5.26 \\
6.40 \pm 4.33\end{array}$} & \multicolumn{2}{|c|}{$\begin{array}{l}10.0(7.0-14.0) \\
6.0(3.0-9.0)\end{array}$} & 0.001 \\
\hline
\end{tabular}

Note: ${ }^{*} p$ value of the Mann-Whitney $U$ test; ${ }^{* *} p$ value of the Kruskal-Wallis test.

Table 3: Correlation analysis between COVID-19 related stressors and the nursing students' anxiety $(\mathrm{N}=316)$.

\begin{tabular}{|l|l|}
\hline Stressors & $\begin{array}{l}\text { Generalized Anxiety } \\
\text { Disorder-7 Scale }\end{array}$ \\
\hline Family problems & $r=0.316^{* *}$ \\
\hline Educational problems & $r=0.122^{*}$ \\
\hline Economic problems & $r=0.211^{* *}$ \\
\hline Restricted social life & $r=0.322^{* *}$ \\
\hline Health problems & $r=0.225^{* *}$ \\
\hline
\end{tabular}

Note: ${ }^{*} p<0.05 ;{ }^{* *} p<0.001$.

The students' anxiety levels had weak negative relationships with the self-confident approach, the optimistic approach and seeking social support $(r=-0.301$ $p=0.000, r=-0.209 p=0.000, r=-0.219 p=0.000$, respectively). They had positive relationships with the desperate and the submissive approaches $(r=0.144 p=$ $0.011, r=0.134 p=0.021$, respectively) (Table 5).

\section{Discussion}

The nursing students had moderate anxiety during the COVID-19 pandemic. A quantitative study carried
Table 4: The distribution of the students' coping strategies ( $\mathrm{N}$ $=316)^{*}$.

\begin{tabular}{|l|l|}
\hline $\begin{array}{l}\text { How do you cope with anxiety during the } \\
\text { pandemic? }\end{array}$ & $\mathbf{n}(\%)$ \\
\hline Eat & $152(48.1 \%)$ \\
Sleep & $175(55.4 \%)$ \\
Listen to music & $211(66.8 \%)$ \\
Watch movies/TV & $229(72.5 \%)$ \\
Read books & $188(59.5 \%)$ \\
Spend time on the internet & $246(77.8 \%)$ \\
Exercise & $122(38.6 \%)$ \\
\hline
\end{tabular}

Note: *The students gave multiple responses.

out with nursing students during the COVID-19 pandemic found high levels of anxiety [10], and qualitative studies found that students were concerned and scared $[8,23]$. In China, $75 \%$ of the students at a medical college had normal levels of anxiety [11]. Different results on this subject are normal considering the number of cases/deaths in Turkey and other countries where relevant studies were conducted, the regions where students live and when the data were collected during the pandemic. Studies conducted before the pandemic 
Table 5: The relationships between the students' subscale scores on the anxiety and stress coping strategies scales ( $N$ $=316)$.

\begin{tabular}{|l|l|}
\hline $\begin{array}{l}\text { Subscales of the Stress } \\
\text { Coping Strategies Scale }\end{array}$ & $\begin{array}{l}\text { Generalized Anxiety } \\
\text { Disorder-7 Scale }\end{array}$ \\
\hline Self-confident Approach & $r=-0.301^{* *}$ \\
\hline Optimistic Approach & $r=-0.209^{* *}$ \\
\hline Desperate Approach & $r=0.144^{* *}$ \\
\hline Submissive Approach & $r=0.134^{*}$ \\
\hline Seeking Social Support & $r=-0.219^{* *}$ \\
\hline
\end{tabular}

Note: ${ }^{*} p<0.05 ;{ }^{* *} p<0.001$.

have also found, like this study, that nursing students had moderate anxiety [24-26].

The students who lived in the Marmara region had higher anxiety levels than students living in other regions. A qualitative study carried out in the Western Black Sea region of Turkey found that nursing students had anxiety, but did not specify the level [8]. According to the latest data of Republic of Turkey Ministry of Health (June 30, 2020), the highest number of COVID cases and deaths is in the Marmara region [3]. This may be why the students living in this region had higher anxiety levels than the others.

The students who had jobs during the pandemic had higher anxiety. A study found that students with jobs had higher anxiety median values; however, this difference was not significant. Considering the mode of transmission of COVID-19, the students with jobs may have had significantly higher anxiety levels because they were at higher risk. This difference may also involve factors such as the characteristics of work environments, following the isolation rules, protective equipment, when the data were collected and the numbers of cases in the cities where the students worked.

There was a positive relationship between the stressors related to COVID-19, including economic, social life, educational, family and health issues, and anxiety. The results of previous studies support this result [6,10-12]. Some families lost their source of income because of the pandemic. Measures such as school closures, social distancing, face masks, lockdowns and travel restrictions have been implemented throughout Turkey. Since the first case in Turkey, the numbers of cases and deaths has increased quickly. The students have experienced serious anxiety because of economic uncertainties, fear for the health of their families, fear of infection and difficulties with distance education. These factors indicate that students' psychological health may be negatively affected by the pandemic.

The students used a variety of coping behaviors during the pandemic. Their most common coping strategy was spending time on the internet. Previous studies have shown that there was an increase in the use of technology and the duration of time spent on the internet during the pandemic [27-29]. Qualitative and quantitative studies have found that the reasons for increased internet usage were: More online conversations with family and friends because of social isolation, boredom, increased homework because of distant learning and trying to get more information about COVID-19 [27,28,30,31]. Understanding the nursing students' coping strategies during the COVID-19 pandemic and quarantine may help to develop more functional and effective intervention strategies.

There was a strong relationship between self-confident approach and seeking social support among the anxiety coping strategies used by the students. Other studies have also found that nursing students use the self-confident approach and seeking social support most [24,32-34]. Social support not only reduces psychological pressure during epidemics, but also changes attitudes toward the methods of seeking social support and help. The results of this study are similar to those in the literature.

\section{Limitations of Study}

The limitations of this study include cross-sectional design, which did not allow a causal conclusion. The second limitation concerns the convenience sample. Our sample is not representative. The results of this study are limited by its data collection tools and by the self-reported opinions of the students. The answers of those interviewed cannot claim to be representative of all nursing students.

\section{Conclusions and Recommendations}

During the pandemic, $40.5 \%$ of the nursing students experienced moderate anxiety. The students who lived in the Marmara region and who had jobs had higher anxiety levels. Stress factors related to COVID-19, including economic, social life, educational, family and health issues, were positively correlated with the anxiety level of the nursing students during the pandemic. There were negative relationships between the self-confident approach, seeking social support and anxiety.

The government and Counsel of Higher Education should cooperate to provide students with qualified, crisis-oriented and psychological services. It is important for universities to support their students.

Before nursing students go to clinical practice in the pandemic, students anxiety symptoms could be assessed mental health nursing courses, which might enable to change their attitudes towards to cope with this situation. Especially during pandemic, nursing students should be supported by mental health nurses to cope with anxiety. Their skills for effective coping can be reinforced.

\section{Acknowledgment}

I would like to thank all the students for their participation in the research. 


\section{Conflict of Interests}

I declare that I have no conflict of interests.

\section{Funding}

No funding had been needed for this survey

\section{Author' Contributions}

Study design, Manuscript drafting, Statistical analyses, Data collection.

\section{References}

1. World Health Organization (2020) WHO announces COVID-19 outbreak a pandemic.

2. Daily Sabah (2020) Turkey remains firm, calm as first coronavirus case confirmed.

3. Republic of Turkey Ministry of Health (2020) COVID-19 Situation Report Turkey.

4. Sahu $P(2020)$ Closure of universities due to coronavirus disease 2019 (COVID-19): Impact on education and mental health of students and academic staff. Cureus 12: e7541.

5. Viner RM, Russell SJ, Croker H, Packer J, Ward J, et al. (2020) School closure and management practices during coronavirus outbreaks including COVID-19: A rapid systematic review. Lancet Child Adolesc Health 4: 397-404.

6. Wang C, Cheng Z, Yue XG, McAleer M (2020) Risk management of COVID-19 by universities in China. J Risk Financial Manag 13: 36.

7. Council of Higher Education (2020) Koronavirüs (COVID-19) bilgilendirme notu: 1 .

8. Kürtüncü M, Kurt A (2020) Problems experienced by nursing students about distance education in the period of COVID-19 pandemic. Journal of Eurasian Social and Economic Research 7: 66-77.

9. Beiter R, Nash R, McCrady M, Rhoades D, Linscomb M, et al. (2015) The prevalence and correlates of depression, anxiety, and stress in a sample of college students. J Affect Disord 173: 90-96.

10. Savitsky B, Findling Y, Ereli A, Hendel T (2020) Anxiety and coping strategies among nursing students during the COVID-19 pandemic. Nurse Educ Pract 46: 102809.

11. Cao W, Fang Z, Hou G, Han M, Xu X, et al. (2020) The psychological impact of the COVID-19 epidemic on college students in China. Psychiatry Res 287: 112934.

12. Lee J (2020) Mental health effects of school closures during COVID-19. Lancet Child Adolesc Health 4: 421.

13. Altiok Ö, Üstün B (2013) The stress sources of nursing students. Educational Sciences: Theory \& Practice 13: 760766.

14. Edwards D, Burnard P, Bennett K, Hebden U (2010) A longitudinal study of stress and self-esteem in student nurses. Nurse Educ Today 30: 78-84.

15. Ergin E, Çevik K, Pakiş Çetin S (2018) An investigation of nursing students' perceptions and coping behaviors of education related stress. Journal of Education and Research in Nursing 15: 16-22.

16. Seyedfatemi N, Tafreshi M, Hagani H (2007) Experienced stressors and coping strategies among Iranian nursing students. BMC Nurs 6: 11.

17. Güler Ö, Çinar S (2010) Determining to the perceived stressors and the used coping strategies of the nursing department students. Maltepe Üniversitesi Hemşirelik Bilim ve Sanati Dergisi 3: 253-260.

18. Özkan S, Yilmaz E (2010) Adaptation Status of University Students to University Life (Bandirma Example). Firat Sağlik Hizmetleri Dergisi 5: 153-170.

19. Spitzer RL, Kroenke K, Williams JBW, Löwe B (2006) A brief measure for assessing generalized anxiety disorder: The GAD-7. Arch Intern Med 166: 1092-1097.

20. Konkan R, Şenormanci Ö, Güçlü O, Aydin E, Sungur MZ (2013) Validity and reliability study for the Turkish adaptation of the Generalized Anxiety Disorder-7 (GAD-7) Scale. Archives of Neuropsychiatry 50: 53-58.

21. Folkman S, Lazarus RS (1980) An analysis of coping in a middle-aged community sample. J Health Soc Behav 21: 219-239.

22. Şahin N, Durak A (1995) A brief of coping styles inventory for university students. Türk Psikoloji Dergisi 10: 56-73.

23. Collado-Boira EJ, Ruiz-Palomino E, Salas-Media $P$, Folch-Ayora A, Muriach M, et al. (2020) "The COVID-19 outbreak" - An empirical phenomenological study on perceptions and psychosocial considerations surrounding the immediate incorporation of final-year Spanish nursing and medical students into the health system. Nurse Educ Today 92: 104504.

24. Ahmed WAM, Mohammed BMA (2019) Nursing students' stress and coping strategies during clinical training in KSA. J Taibah Univ Med Sci 14: 116-122.

25. Mirón J, Goldberg X, Lopez Sola C, Nadal R, Armario A, et al. (2019) Perceived stress, anxiety and depression among undergraduate students: An online survey study. J Depress Anxiety 8: 330 .

26. Şahin G, Buzlu S (2017) The mediating role of perceived stress on relationship of resilience with self efficacy social support and the effective coping skills in nursing students. Journal of Anatolia Nursing and Health Sciences 20: 122136.

27. Saltzman LY, Hansel TC, Bordnick PS (2020) Loneliness, isolation, and social support factors in post-COVID-19 mental health. Psychological Trauma 12: S55-S57.

28. Hatun O, Dicle AN, Demirci İ (2020) Psychological reflections of the coronavirus pandemic and coping with pandemic. Electronic Turkish Studies 15: 531-554.

29. Gao J, Zheng P, Jia Y, Chen H, Mao Y, et al. (2020) Mental health problems and social media exposure during COVID-19 outbreak. PLoS One 15: e0231924.

30. Bilge $Y$, Bilge $Y(2020)$ Investigation of the effects of coronavirus and social isolation on psychological symptoms in terms of psychological resilience and coping styles. Journal of Clinical Psychiatry 23: 38-51.

31. Kirman F (2020) Psychology of pandemia in social media: Perception, effect and coping. World Journal of Human Sciences, 11-44.

32. Chen Q, Liang M, Li Y, Guo J, Fei D, et al. (2020) Mental health care for medical staff in China during the COVID-19 outbreak. Lancet Psychiatry 7: e15-e16.

33. Yilmaz M, Yaman Z, Erdoğan S (2017) Stressful situation in nursing students and the methods of coping with stress. Mersin University the Journal of Health Sciences 10: 88-99.

34. Thompson G, McBride RB, Hosford CC, Halaas G (2016) Resilience among medical students: The role of coping style and social support. Teach Learn Med 28: 174-182. 